\title{
Cerrado: Agricultural Production and Areas Designated for Environmental Preservation Registered in the Brazilian Rural Environmental Registry (Cadastro
} Ambiental Rural)

\author{
Gisele Freitas Vilela, André Rodrigo Farias, Fernando Antônio de Pádua Paim, Gustavo Spadotti A. Castro, \\ Osvaldo Tadatomo Oshiro and Carlos Alberto de Carvalho \\ Embrapa Territorial, Campinas 13070115, Brazil
}

\begin{abstract}
In this study, authors analyzed value, production and area used for producing Cerrado's main agricultural products, and data on the farms located within this biome and registered in CAR up until April 2019, by microregion. The territory considered here comprised all microregions with at least $25 \%$ of its area covered by the Cerrado biome. The production, agricultural production, and planted area values used were the averages of the 2015 to 2017 harvests, and are shown in graphs and tables, as are maps of planted areas and groups of main annual crops, semi-perennial and perennial crops. The areas designated for environmental preservation (ADPs) are the result of the sum of permanent preservation areas (APP), legal reserves (RL) and additional vegetation areas within the farms. Authors' study shows that most of Brazilian cotton, eucalyptus for charcoal, orange, sugarcane, maize and soybean are produced in Cerrado, that $28 \%$ of Cerrado are ADPs within farms, and that $16 \%$ are areas planted with cotton, eucalyptus, orange, sugarcane, maize, soybean, coffee, beans, and potatoes. The territory occupied by agricultural areas and ADPs required by the Brazilian Forest Code shows that agricultural production and environmental preservation do coexist, and gather the maintenance of essential ecosystem services provided by the ADPs together with the development of the country's relevant agricultural production.
\end{abstract}

Key words: Brazilian Rural Environmental Registry, Cerrado, Brazilian Forest Code, environmental preservation, agricultural production.

\section{Introduction}

Over the last two decades, Brazilian agribusiness has made its agriculture diverse, created agroindustries to add value to products, and expanded its exports with new products to new markets [1]. Agribusiness has been driving Brazilian economy forward. Boasting US\$ 102.14 billion revenue in exports in 2018, it employs one out of three people in the country, and accounted for $21.6 \%$ of the country's gross domestic product (GDP) in 2017 [2].

Following the introduction of new agricultural technologies suitable for Cerrado's typical soils in the

Corresponding author: Gisele Freitas Vilela, Ph.D., Researcher, main research field: territorial management. 1970s, agricultural production developed itself and began advancing its territory and occupying the country's Central-West and Northeast regions.

Several scientists advised of the damaging effects of an uncontrolled agricultural expansion to Cerrado's environment, and pointed to a commonplace: the need to assure the maintenance of areas for environmental protection and conservation [3-6].

Regarding the challenges faced in a consonant coexistence of natural resources and agribusiness, Lopes and Daher [7] appraise that actions for the deployment of the Brazilian Forest Code would be important to produce a reasonable and sustainable framework for the exploitation of this wide region. Ten years have passed, and although the Forest Code 

the Brazilian Rural Environmental Registry (Cadastro Ambiental Rural)

referred to by the authors was replaced by the current one in 2012, the New Forest Code has kept as mandatory that at least $20 \%$ of the farm's area be reserved for environmental preservation. This percentage increases in areas of great ecological and biodiversity interest, such as areas within the Amazon biome.

Technology is also essential for sparing scarce natural resources: 171 million hectares are estimated to have been spared in Brazilian agricultural production between 1985 and 2006, which is nearly 20\% of the country's territory, and this is mainly due to productivity increase [8-10].

The Brazilian Rural Environmental Registry (Cadastro Ambiental Rural, CAR), created by the Brazilian Forest Code (Br. Law no. 12.651, of May 25, 2015), enables registering, for each farm, its location, its perimeter, its native forest remnants, permanent preservation areas, restricted use areas, consolidated and legal reserve areas. CAR is registered using Brazilian Rural Environmental Registry National System (SICAR), a nation-wide electronic system coordinated by the Brazilian Forest Service. The information available in SICAR are used as basis for public policies, programs, projects, monitoring and planning actions, and for fighting illegal logging. Thus, CAR data enable real-time, consistent assessment of the areas designated for environmental preservation in farms, and secured by law. It is worth highlighting that no inference is made here regarding the type of or state of the native vegetation within these farms.

The Brazilian environmental law determines that different percentages of areas are to be preserved as legal reserves within farms, according to the biome in which the farm is located. For example, farms located within the Legal Amazon and those located within the Cerrado biome are required to designate $35 \%$ of the farm's total area for environmental preservation in the form of legal reserves. The Legal Amazon encompasses the states which are part of the Amazon basin, and includes all the states in the North region, as well as the whole of Mato Grosso and most of Maranhão. Somewhat differently, farms located in the Cerrado biome and which are not within the Legal Amazon region must designate $20 \%$ of their total area as legal reserves. Farms within the Amazon biome must designate at least $80 \%$ of their areas as legal reserves.

In this context, our study aimed to analyze agricultural production in the Cerrado biome, and analyze data about areas designated for environmental preservation in farms registered in CAR up until April 2019, by microregion.

\section{Material and Methods}

Authors' study area, the Cerrado biome spreads over the central portion of the Brazilian territory, and stretches from the shoreline of the state of Maranhão throughout portions of the states of Piauí, Bahia, Mato Grosso, Mato Grosso do Sul, to nearly the whole of Tocantins and Goiás, the whole of the Brazilian Federal District (Distrito Federal, DF), to small portions of Rondônia and Pará, reaches over half of the state of Minas Gerais and a third of the state of São Paulo, and finally a small portion in the state of Paraná. The Cerrado biome occupies 203.4 million hectares, approximately 24\% of the Brazilian territory [11] (Fig. 1). Cerrado "lato sensu" - a savannah phytophysiognomy - is a complex of several plant formations, from grassland vegetation to 'cerradão', which is a forest formation, and encompasses a series of intermediate vegetation forms (known as campo sujo, campo cerrado and cerrado "stricto sensu", in Portuguese). Riparian formations (veredas and mata de galeria, in Portuguese) are also part of the Cerrado biome [12-14].

With the aim of making the physical boundaries of the Cerrado biome Fig. 1 ) compatible with the country's political and administrative structure, all microregions covered by Cerrado in at least $25 \%$ of their areas were taken into account in this study's analyses Fig. 2). Cerrado portions within the states of Paraná, Rondônia and Pará were disregarded in this study, because they 
Cerrado: Agricultural Production and Areas Designated for Environmental Preservation Registered in the Brazilian Rural Environmental Registry (Cadastro Ambiental Rural)

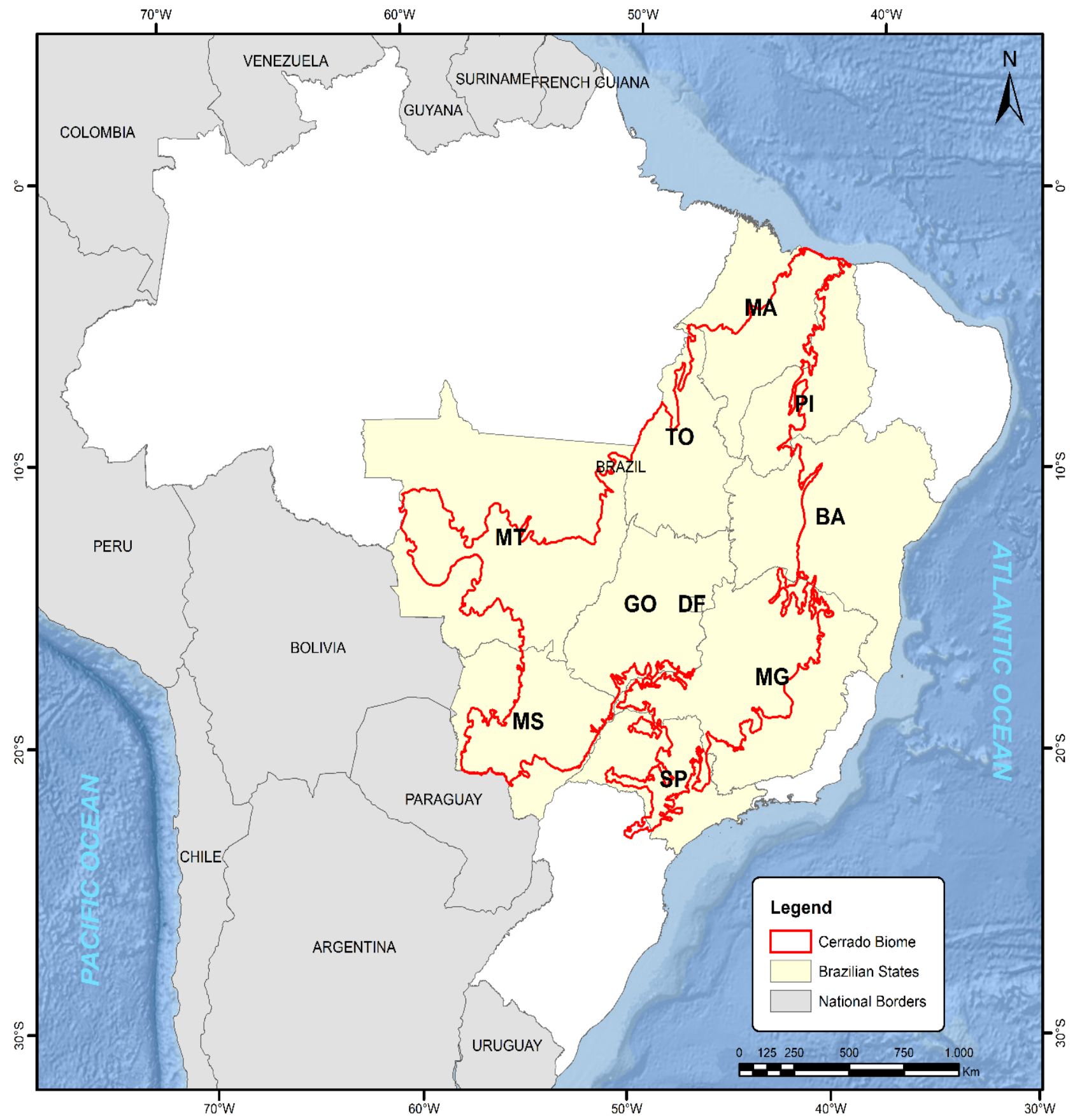

Fig. 1 Location of the Cerrado biome in Brazil.

were not representative in terms of total agricultural production.

Microregion data correspond to data on the cities which are partly or totally located within the Cerrado biome. "Cerrado" will be our term of choice to refer to the study area in this paper.

Due to the regularity of the microregions' boundaries, we chose to use them as territory boundaries instead of using city boundaries, because these change more dynamically than those over time.

Cerrado's most representative agricultural products were analyzed in terms of production value, total production and planted area: cotton, eucalyptus, orange, sugarcane, maize, soybean, coffee, bean and potato. 

the Brazilian Rural Environmental Registry (Cadastro Ambiental Rural)

The results obtained are the averages of the values from 2015 to 2017.

The data on agricultural production were grouped in four production quarters, according to Garagorry and Chaib [15]. Quarter Q4 is the group that concentrates $25 \%$ of the production, called G25. The sum of Q4 and Q3 forms the group that concentrates $50 \%$ of the production, named G50. Q4, Q3 and Q2 together account for $75 \%$ of the production, hence $\mathrm{G} 75$.

According to the New Brazilian Forest Code of 2012, the Brazilian Rural Environmental Registry (CAR) [16] became a mandatory electronic registry for all farms. Using this spatial database on farms and their vegetation areas, Embrapa Territorial used geoprocessing techniques and tools to produce cartographic measurements and calculations on the areas dedicated to the preservation of native vegetation throughout this set of farms. Thus, we were able to detect, identify, qualify, quantify and map the areas which are designated for preservation in the farms registered in CAR using homogeneous and unified bases [17]. This geocoded data were queried and processed hierarchically by biome, state, city and up to each individual farm. All of our method's steps and phases are detailed and available under Embrapa [18]. The data were downloaded from CAR from March 26 to April 15, 2019. The computer systems used for processing the spatial database analysis carried out in this study are based on large-capacity, strong-performance equipment: 5 HP Intel Core i7, 3.4GHz, 16-GB RAM, 500-GB SSD HD, and 2-TB HD workstations; 1 SY480Gen10 Blade server equipped with 10-core Intel Xeon Silver processors, 192-GB RAM and 2 600-GB HDs, and a 192-TB HP MSA-2050 storage.

The main software used was ArcGIS, due to its capacity to process large spatial databases and its specialized modules for spatial analyses. All operations involving tabular data were performed using Microsoft Excel and its functions. Other software used were: ESRI ArcGIS for Desktop 10.7 equipped with the Spatial Analyst and Geo-statistical modules [19];
Google Earth Pro [20]; File Geo-database supported by ArcGIS 10.7 [21], and Microsoft Office equipped with Microsoft Excel for statistical functions.

All areas designated for environmental preservation (ADPs) in the farms registered in CAR were grouped and quantified by microregion. The ADPs are the result of the sum of permanent preservation areas (APP), legal reserves $(\mathrm{RL})$ and additional vegetation areas within the farms. All native vegetation areas within the farms which did not qualify as APP or RL were classified as 'additional vegetation'. According to the Brazilian Forest Code, additional vegetation may not be deforested, but may be included in the environmental compensation program of other farms. It is worth highlighting that the CAR data used encompass all productive farms, not only the ones that produce the crops analyzed in this study.

Authors used the R statistical system [22] to produce the graphs, and the ArcGIS 10.6 software to create the maps and classify the analyzed areas.

\section{Results and Discussion}

Authors' Cerrado selection encompassed an area featuring 234.9 million hectares, 132 microregions, and 1,394 cities (Fig. 2).

The farms registered in CAR and located in Cerrado areas amount to 1 million and 47 thousand units, and their total area covers 166 million hectares or $70.7 \%$ of the whole area (Table 1).

Brazilian Federal District, Goiás and Tocantins are fully inserted in the Cerrado biome. Mato Grosso has the largest Cerrado area when compared to the remaining states, 20.3\% (Table 1). Cotton, sugarcane, orange, maize, soybean and beans account for more than $50 \%$ of the country's total production value (Table 2 ).

Soybean has the highest production value, followed by sugarcane, maize and coffee (Fig. 3).

In terms of total production value, the country's most relevant vegetables are potatoes (40\%), and the mostrelevant forest product is eucalyptus (41\%) (Table 2 and Fig. 3). 
Cerrado: Agricultural Production and Areas Designated for Environmental Preservation Registered in the Brazilian Rural Environmental Registry (Cadastro Ambiental Rural)

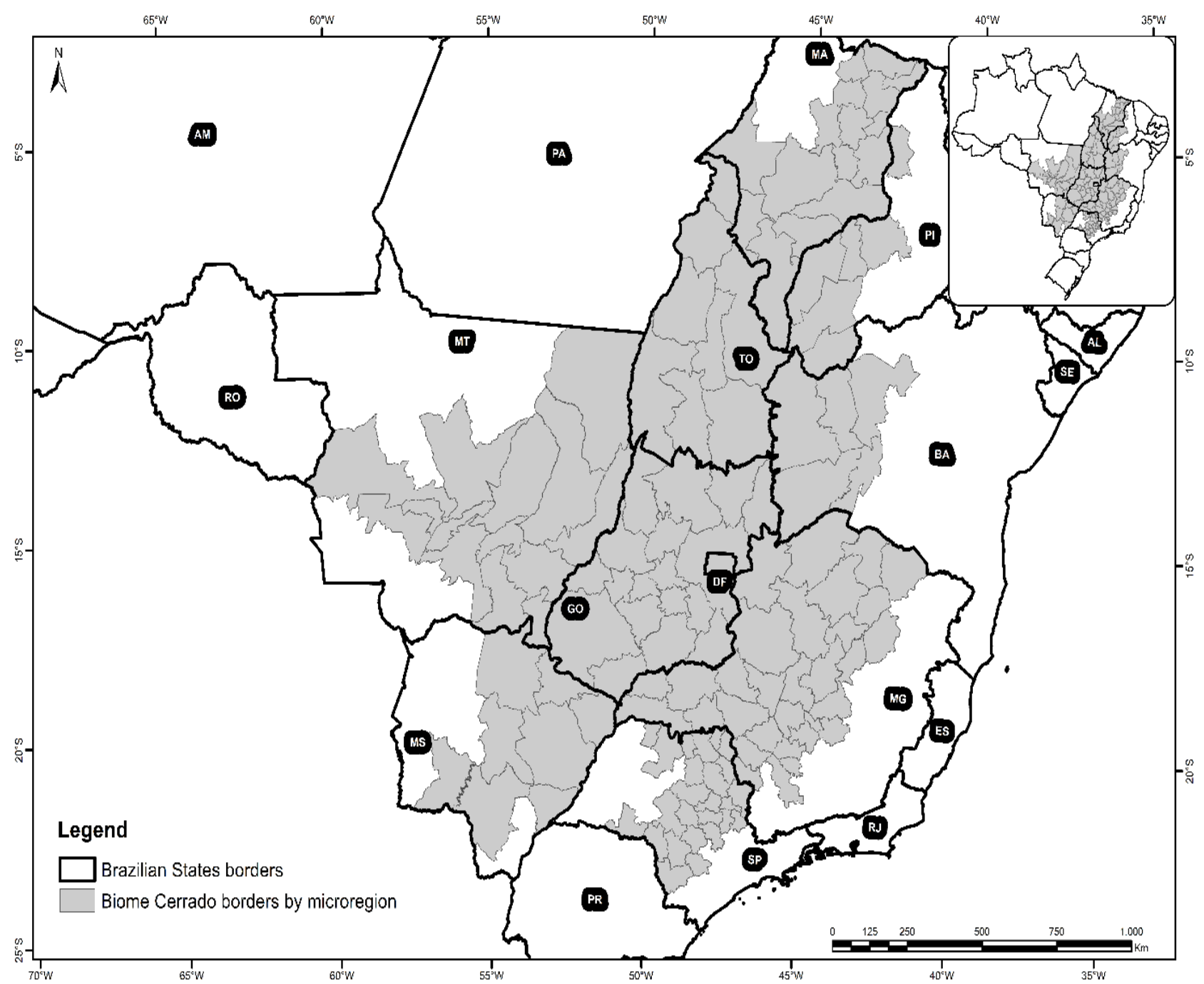

Fig. 2 Cerrado areas selected for use in this study. This selection encompasses the microregions which have at least $25 \%$ of their territories covered by Cerrado biome.

Table 1 Territorial dimension of Cerrado and the states, number and area of the farms registered in the Brazilian Rural Environmental Registry.

\begin{tabular}{|c|c|c|c|c|c|}
\hline \multirow{3}{*}{ States } & \multirow{2}{*}{ Cerrado areas } & \multicolumn{4}{|c|}{ Cerrado participation } \\
\hline & & Cerrado & State & CAR farms area & CAR number of farms \\
\hline & hectares & & & hectares & Units \\
\hline PI & 10923911 & 4.7 & 43.4 & 6021310 & 32742 \\
\hline SP & 11609477 & 4.9 & 46.8 & 9682628 & 159915 \\
\hline BA & 16455375 & 7.0 & 29.1 & 9820539 & 78178 \\
\hline MS & 22391158 & 9.5 & 62.7 & 19734797 & 48254 \\
\hline MA & 24606449 & 10.5 & 74.1 & 13469137 & 69370 \\
\hline TO & 27772057 & 11.8 & 100 & 17581197 & 69834 \\
\hline GO/DF & 34589138 & 14.7 & 100 & 26830382 & 163149 \\
\hline MG & 38850581 & 16.5 & 66.2 & 28500575 & 364329 \\
\hline MT & 47716378 & 20.3 & 52.8 & 34535354 & 62127 \\
\hline Total & 234914524 & & & 166175920 & 1047898 \\
\hline
\end{tabular}

Source: [23, 24]. 

the Brazilian Rural Environmental Registry (Cadastro Ambiental Rural)

Table 2 Production value for all agricultural products in Cerrado (average for the 2015/2016/2017 harvests).

\begin{tabular}{lrrr}
\hline \multicolumn{1}{c}{ Agricultural products } & Production value & \\
\hline \multicolumn{1}{c}{ Cerrado } & Brazil & \multicolumn{1}{c}{ Brazil Cerrado participation } \\
\hline Cotton & & 7392139 & 98 \\
Sugar cane & 7219233 & 49811929 & 65 \\
Orange & 32475983 & 7543145 & 59 \\
Maize & 4469559 & 33437605 & 56 \\
Soy & 18557896 & 102511855 & 54 \\
Bean & 55288273 & 7569038 & 51 \\
Eucalyptus & 3845368 & 10514267 & 45 \\
Potato & 4784443 & 4323655 & 40 \\
Coffee & 1719901 & 18587069 & 38 \\
Total & 7143473 & 231176435 & 57 \\
\hline
\end{tabular}

Source: [25].

Table 3 Agricultural production and planted area for Cerrado's main agricultural products (average for the 2015/2016/2017 harvests).

\begin{tabular}{|c|c|c|c|c|c|c|}
\hline \multicolumn{4}{|c|}{ Production media } & \multicolumn{3}{|c|}{ Planted area } \\
\hline Products & Cerrado & Brazil & $\begin{array}{c}\text { Brazil participation } \\
\text { of Cerrado } \\
\text { agricultural } \\
\text { production } \\
\end{array}$ & Cerrado & Brazil & $\begin{array}{c}\text { Brazil } \\
\text { participation } \\
\text { of Cerrado } \\
\text { agricultural area } \\
\end{array}$ \\
\hline \multicolumn{2}{|c|}{ Tonnes } & & $\%$ & \multicolumn{2}{|c|}{ Hectares } & $\%$ \\
\hline Cotton & 3693725 & 3771434 & 98 & 957671 & 988062 & 97 \\
\hline Eucalyptus (coal) & 4076979 & 5035292 & 81 & & & \\
\hline Orange & 12175976 & 17220619 & 71 & 402731 & 663025 & 61 \\
\hline Sugar cane & 495097851 & 759134095 & 65 & 6380793 & 10217144 & 62 \\
\hline Maize & 47690287 & 82382783 & 58 & 9002594 & 16530700 & 54 \\
\hline Soy & 56515044 & 102819641 & 55 & 18739935 & 33175466 & 56 \\
\hline Bean & 1438310 & 2912592 & 49 & 892590 & 3048473 & 29 \\
\hline Potato & 1560814 & 3791974 & 41 & 45569 & 126657 & 36 \\
\hline \multirow[t]{2}{*}{ Coffee } & 1097595 & 2783563 & 39 & 657096 & 1932830 & 34 \\
\hline & meters & & & & & \\
\hline Eucalyptus (log) & 9417080 & 25782485 & 36 & & & \\
\hline Eucalyptus (cel.) & 23569454 & 67378796 & 35 & & & \\
\hline Eucalyptus (firewood) & 11872107 & 46867781 & 25 & & & \\
\hline \multirow[t]{2}{*}{ Eucalyptus (total) } & & & & 3521388 & 7474821 & 47 \\
\hline & ads & & & & & \\
\hline Cattle & 86745735 & 216115160 & 40 & & & \\
\hline Poultry & 384023435 & 1368147889 & 28 & & & \\
\hline Pigs & 10828802 & 40281667 & 27 & & & \\
\hline
\end{tabular}

Source: [25]. 


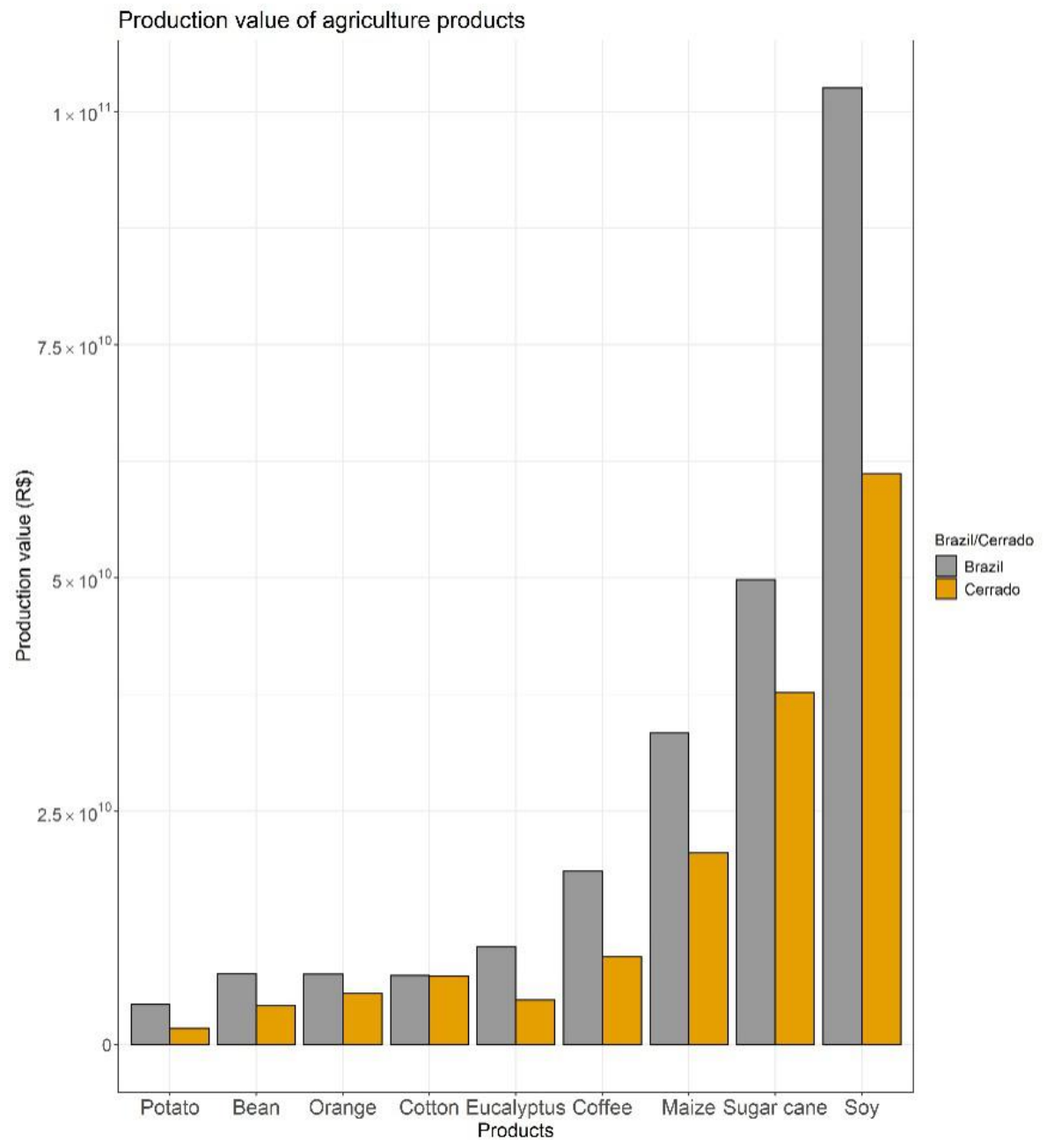

Fig. 3 Production value for the main agricultural products in Cerrado (average for the 2015/2016/2017 harvests).

Table 3 and Fig. 4 show that 98\% of the Brazilian cotton is produced in Cerrado. Cotton is also the most planted crop in terms of planted area.

Another highlight is the eucalyptus charcoal production, which accounts for $81 \%$ of Cerrado's the total production.

Authors divided eucalyptus into categories because these categories occupy different territories, and because charcoal production is measured in tons, while the remainder are measured in cubic meters. Next come orange (71\%), sugarcane (65\%), maize (58\%), soybean (55\%), beans (49\%), and bovines (40\%). In terms of planted area, these are Cerrado' figures: $97 \%$ cotton, $62 \%$ sugarcane, $61 \%$ orange, $56 \%$ soybean, $54 \%$ maize, $47 \%$ eucalyptus, $36 \%$ potato, $34 \%$ coffee and 29\% beans (Table 3 ).
Planted area figures for the main agricultural products compared to Cerrado's total area are shown in Table 4. The average area planted with cotton occupies $0.4 \%$ of Cerrado's total area. However, since part of the cotton crops are planted after soybean, and there are no data available on the first and second cotton harvests, the area planted with cotton was not included in the total planted area figures. Together, soybean and maize (first-harvest) occupy $11 \%$ of Cerrado's planted area.

The total planted area for soybean, maize (first-harvest), sugarcane, orange, eucalyptus, coffee, beans (first-harvest), and potato crops occupied 14.5\% of Cerrado's area.

In terms of planted area, soybean, maize, and sugarcane occupy the largest areas among temporary crops (Fig. 5). 

the Brazilian Rural Environmental Registry (Cadastro Ambiental Rural)

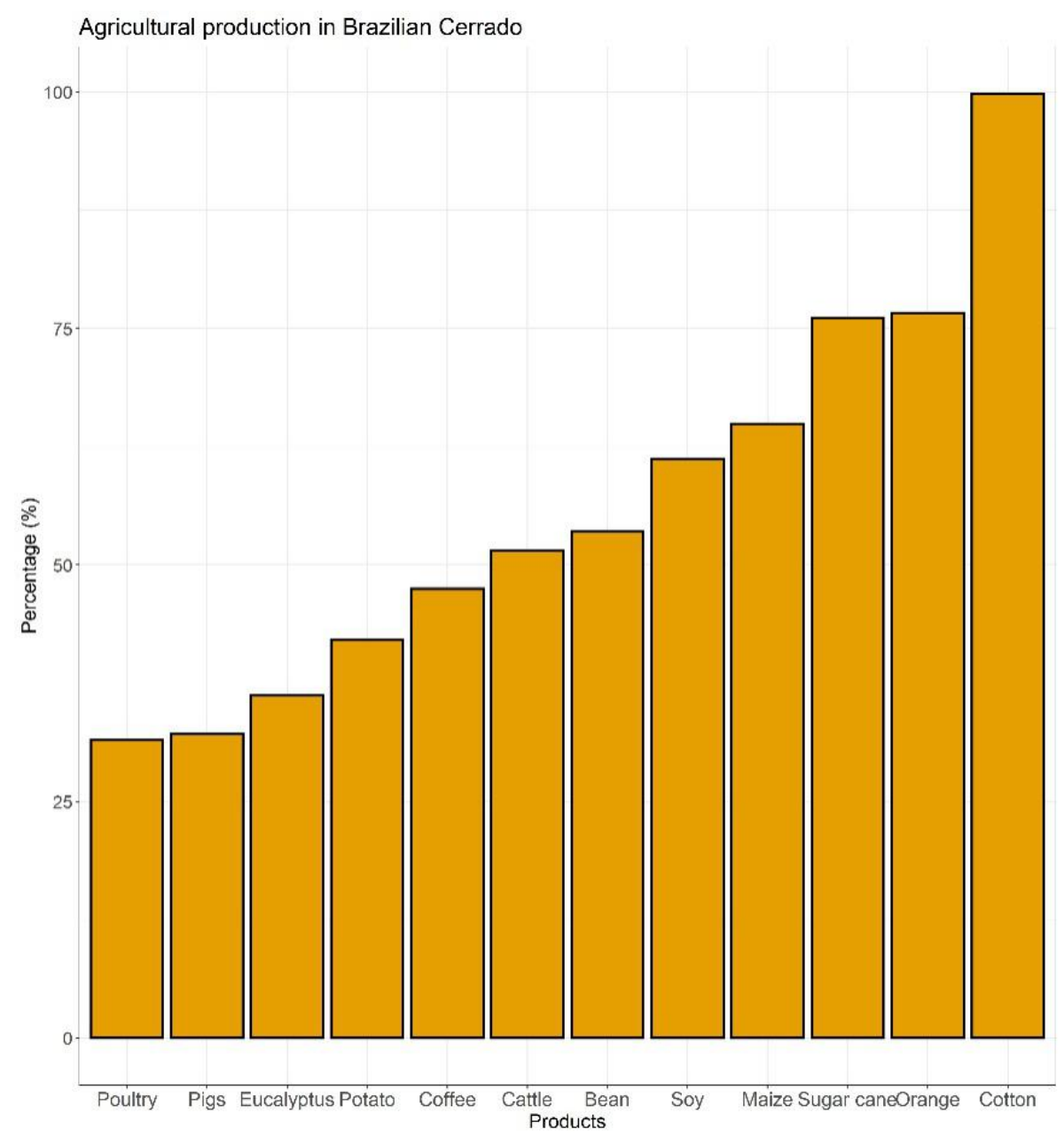

Fig. 4 Average production percentage for Cerrado's main products in comparison to the country's total figures.

Table 4 Planted area and participation compared with total amounts for Cerrado's main agricultural products.

\begin{tabular}{lrc}
\hline \multicolumn{1}{c}{ Products } & Planted area* & Planted area participation of Cerrado total area \\
\hline & hectares & $\%$ \\
Soy & 18739935 & 8 \\
Maize (first-harvest) & 7003618 & 3 \\
Sugar cane & 6380793 & 2.7 \\
Eucalyptus & 3521388 & 1.5 \\
Coffee & 657096 & 0.3 \\
Orange & 402731 & 0.2 \\
Bean (first-harvest) & 371501 & 0.2 \\
Potato & 45569 & 0.02 \\
Total & & 14.5 \\
\hline
\end{tabular}

* average for the 2015/2016/2017 harvests.

Source: [23-25]. 
Cerrado: Agricultural Production and Areas Designated for Environmental Preservation Registered in 95 the Brazilian Rural Environmental Registry (Cadastro Ambiental Rural)

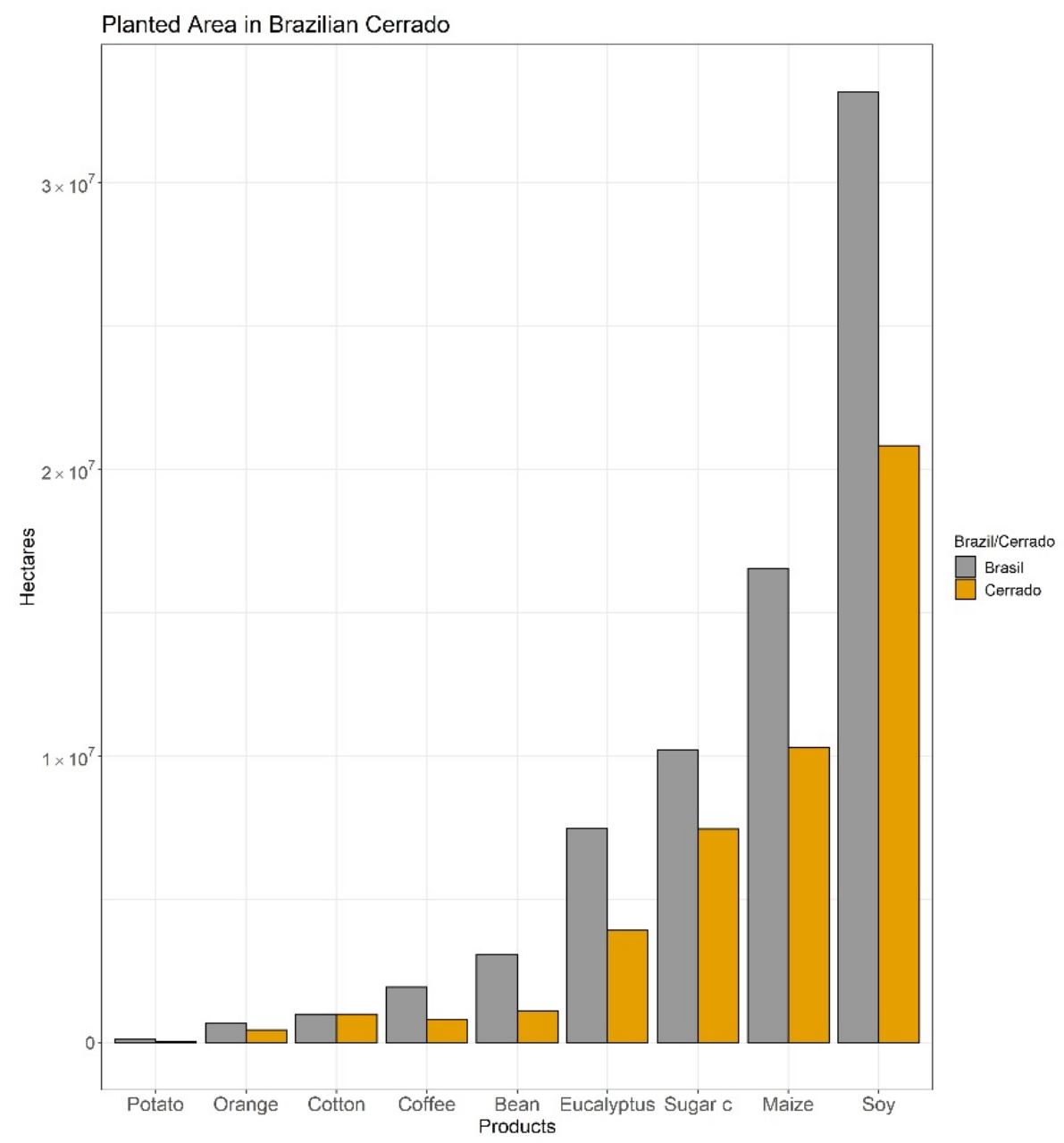

Fig. 5 Planted area for Cerrado's main agricultural products (average for the 2015/2016/2017 harvests).

Table 5 Total amount of areas designated for environmental preservation in farms in Cerrado and in Brazil.

\begin{tabular}{lrccc}
\hline \multicolumn{5}{c}{ Areas designated for environmental preservation (ADPs) } \\
\hline \multirow{2}{*}{ States } & \multicolumn{3}{c}{ Cerrado of States } & Cerrado of Brazil \\
\cline { 2 - 5 } & hectares & ADP/ farms & ADP/ State & ADP/ country \\
\cline { 2 - 5 } MA & 7479042 & 55.5 & 54.7 & 3.2 \\
\hline TO & 9668594 & 55.0 & 63.3 & 4.1 \\
PI & 3607979 & 59.9 & 55.1 & 1.5 \\
BA & 5279587 & 53.8 & 59.7 & 2.2 \\
MATOPIBA & 26035203 & 55.5 & 32.6 & 11.1 \\
GO/DF & 9052874 & 33.7 & 77.6 & 3.9 \\
MT & 15319717 & 44.4 & 72.4 & 6.5 \\
MS & 4596232 & 23.3 & 88.1 & 2.0 \\
MG & 10216377 & 35.8 & 73.4 & 4.3 \\
SP & 1682050 & 17.4 & 83.4 & 0.7 \\
Total & 66902454 & 40.3 & 28.5 & 28.5 \\
Brazil & 193351988 & 48 & 22.7 & \\
\hline
\end{tabular}

Source: [23, 24]. 

the Brazilian Rural Environmental Registry (Cadastro Ambiental Rural)

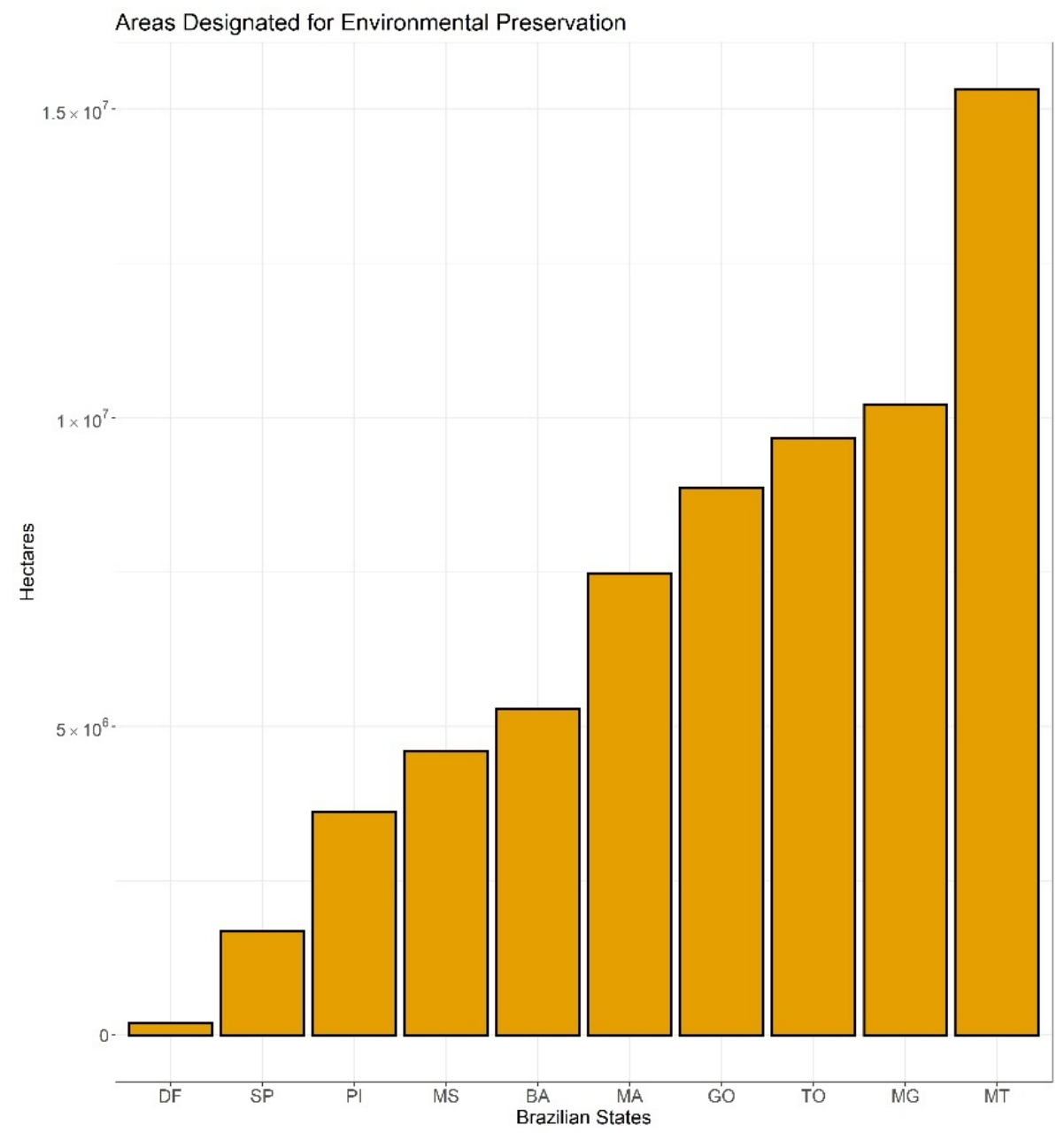

Fig. 6 Areas designated for environmental preservation in farms registered in the Brazilian Rural Environmental Registry and located in Cerrado areas (2018).

Cerrado has a total amount of 66.9 million hectares of ADP, which corresponds to $40.3 \%$ of the farms' areas and to $28.5 \%$ of Cerrado's area (Table 5 and Fig. 6).

Mato Grosso leads the ranking of ADP hectares: $44.4 \%$ of the farms' areas, $72.4 \%$ of the state's Cerrado areas, and $6.5 \%$ of the country's Cerrado areas. It is also the state that contributes the most with ADP areas to the country's Cerrado. The MATOPIBA region concentrates the highest percentages of ADP in farms-between $53.8 \%$ and $59.9 \%$-which corresponds to $32.6 \%$ of the region's Cerrado and to $11.1 \%$ of the country's Cerrado (Table 5).

The data about Mato Grosso do Sul are underestimated, because, unlike the remaining states, it had not migrated the whole of its CAR data on farmers to SICAR until our study was concluded. This explains the small 10.8\% ADP figures for Mato Grosso do Sul in spite of the fact that Cerrado occupies the largest part of the state (Table 5 and Fig. 6). Fig. 7 shows the distribution of the ADPs over Cerrado's microregions. Legal Amazon's boundaries are shown in the map by the different ADP percentages in the Cerrado biome, according to the Brazilian Forest Code for the Legal Amazon, as previously described. Thus, we verified ADP figures above $30 \%$ within the boundaries of the Legal Amazon.

When analyzing areas designated for preservation in Cerrado (Fig. 7), we noted that several microregions in the Central-West and North regions have ADP rates higher than 50\% within the Legal Amazon region. We also verified ADP figures above $40 \%$ in the west region of the state of Bahia and through the whole of Piauí. 


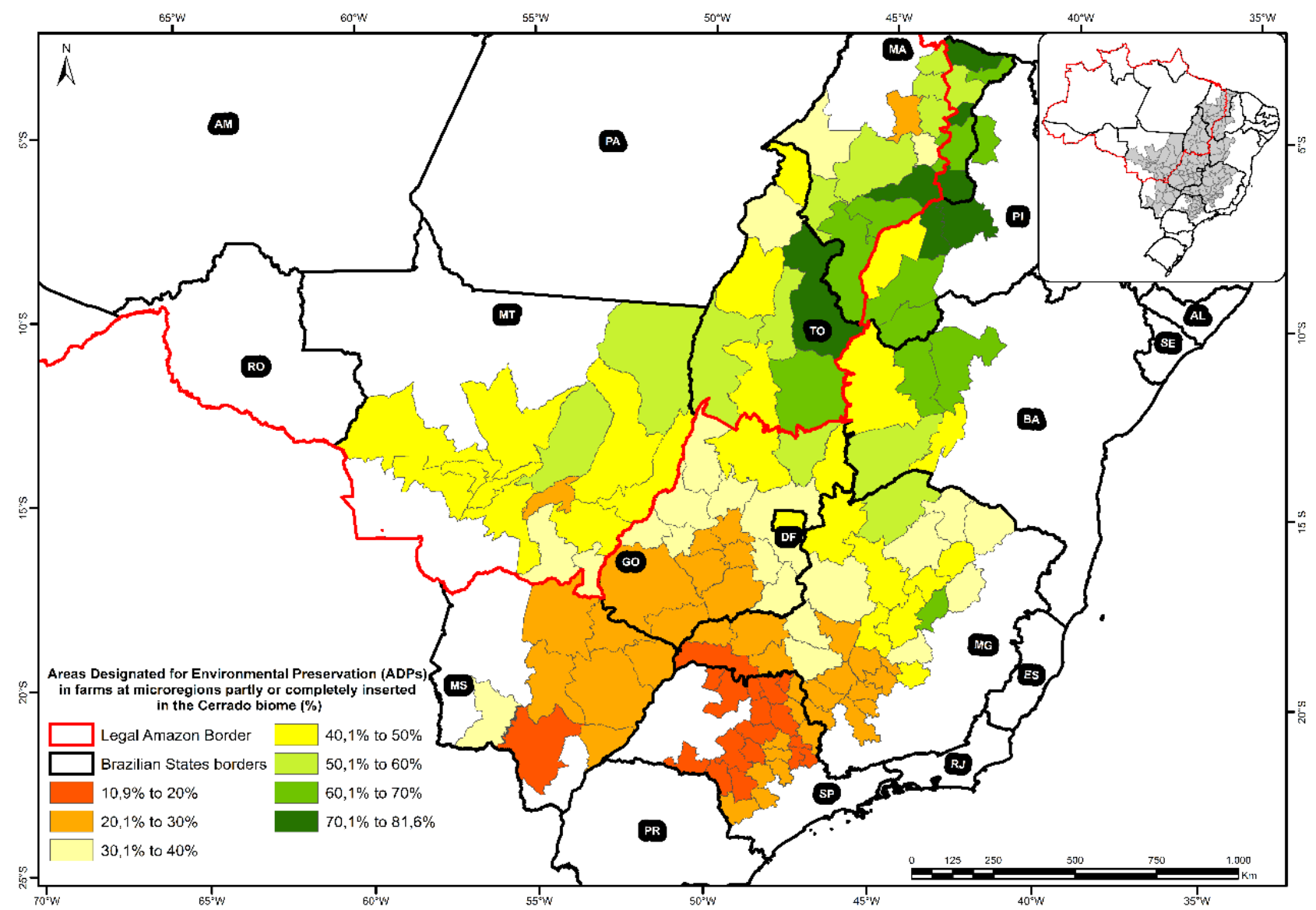

Fig. 7 Areas designated for environmental preservation in farms at microregions partly or completely inserted in the Cerrado biome.

São Paulo shows the lowest ADP value (17.7\%). ADPs in early settled microregions, and which have higher numbers of farms smaller than four fiscal modules may, according to the Brazilian Forest Code, designate less than $20 \%$ of their areas for environmental preservation, as the microregions of the state of São Paulo depict [26]. Microregions located in Matopiba and areas at agricultural boundaries show ADP rates above $60 \%$.

The most relevant agricultural products were selected for a more detailed analysis of their distribution in Cerrado, and were divided into annual crops (soybean and maize) and semiperennial and perennial crops (sugarcane and eucalyptus).

\subsection{Soybean}

Soybean is the agricultural product with the highest added value, and Brazil is ranked as its top exporter and second largest world producer [27].
Soybean production has increased nearly five times from 1990 to 2018, but the planted area has only tripled (Fig. 8), which is an indication of the importance of increasing crop productivity as one of the main factors for production consolidation [28].

The expansion of soybean crops, and the socioeconomic development of Brazilian cities between 1991, 2000, and 2010 were analyzed by Martinelli [29], who detected higher Human Development Index (HDI) in cities that produced soybean in comparison to those which did not, especially those located in agricultural boundaries.

The microregions featuring planted areas above 700 thousand hectares are located in the south portion of Mato Grosso do Sul, in the southwest of Goiás, in the north of Mato Grosso, and in the west portion of Bahia Fig. 9). The microregions of the G50 group (accountable for $50 \%$ of the production, G50 = Q4 + 

the Brazilian Rural Environmental Registry (Cadastro Ambiental Rural)

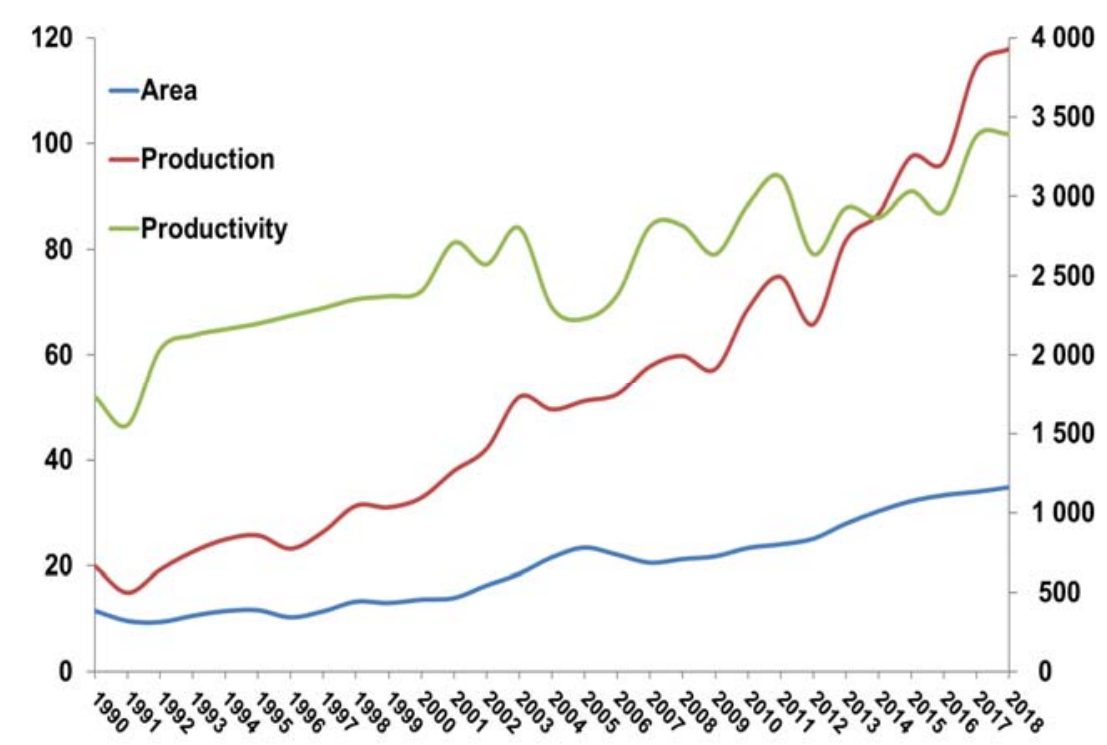

Fig. 8 Planted area, agricultural production and productivity for soybean in Brazil from 1990 to 2018. Source: [25].

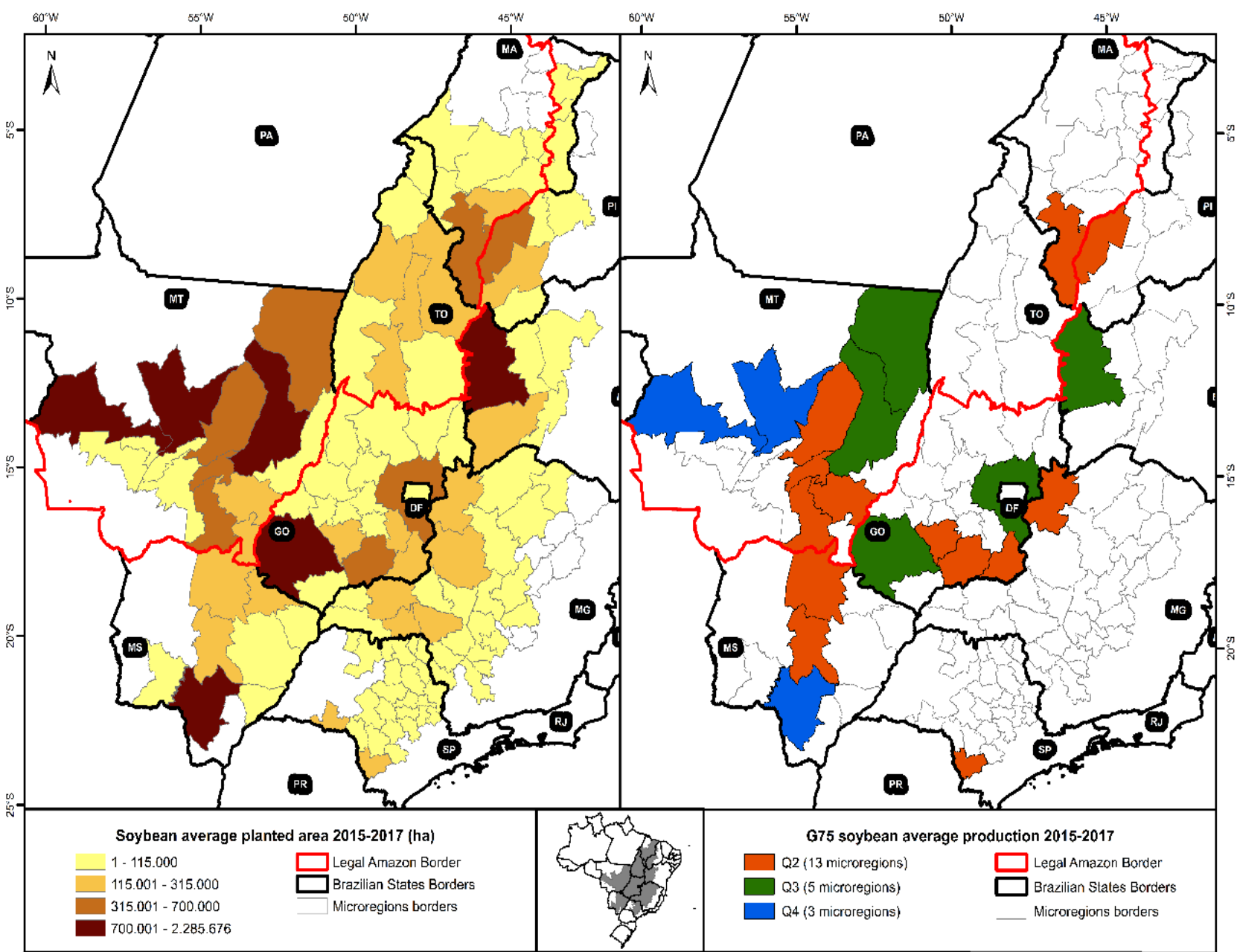

Fig. 9 Planted area and production groups (G75) for soybean at the microregions within the states in the Cerrado biome (average for the 2015/2016/2017 harvests). 

the Brazilian Rural Environmental Registry (Cadastro Ambiental Rural)

Q3) are also the same, plus the microregion around the Brazilian Federal District.

\subsection{Maize}

Brazil is the world's third largest producer and the second largest exporter for maize [27]. The average Brazilian productivity for this crop is of $5400 \mathrm{~kg} / \mathrm{ha}$, but several farmers in different regions are reaching average productivities above $12,000 \mathrm{~kg} / \mathrm{ha}$.

The expansion of maize crops within Cerrado has increased a lot over the last decades, mainly under sequential cropping after soybean, because of early development soybean varieties (Fig. 10).

Second-harvest maize accounted for $77 \%$ of the total amount of maize planted in the last three harvests (on average) analyzed in this study. First-harvest maize crops accounted for $22 \%$ of the total.

Thus, maize production areas are concentrated in the same microregions with high soybean production rates. The Alto Teles Pires, in Mato Grosso, and Sudoeste de Goiás microregions concentrate $25 \%$ of the Brazilian production.

After selecting the microregions with highest soybean and maize production rates using the ADP in Fig. 7 authors obtained the data shown in Table 6.

The microregions showing strongest participation in Brazilian soybean and maize production also show ADP values of $46.3 \%$ at the Barreiras (BA) microregion, 29.2\% at Sudoeste de Goiás, and 39.7\% at Entorno de Brasília.

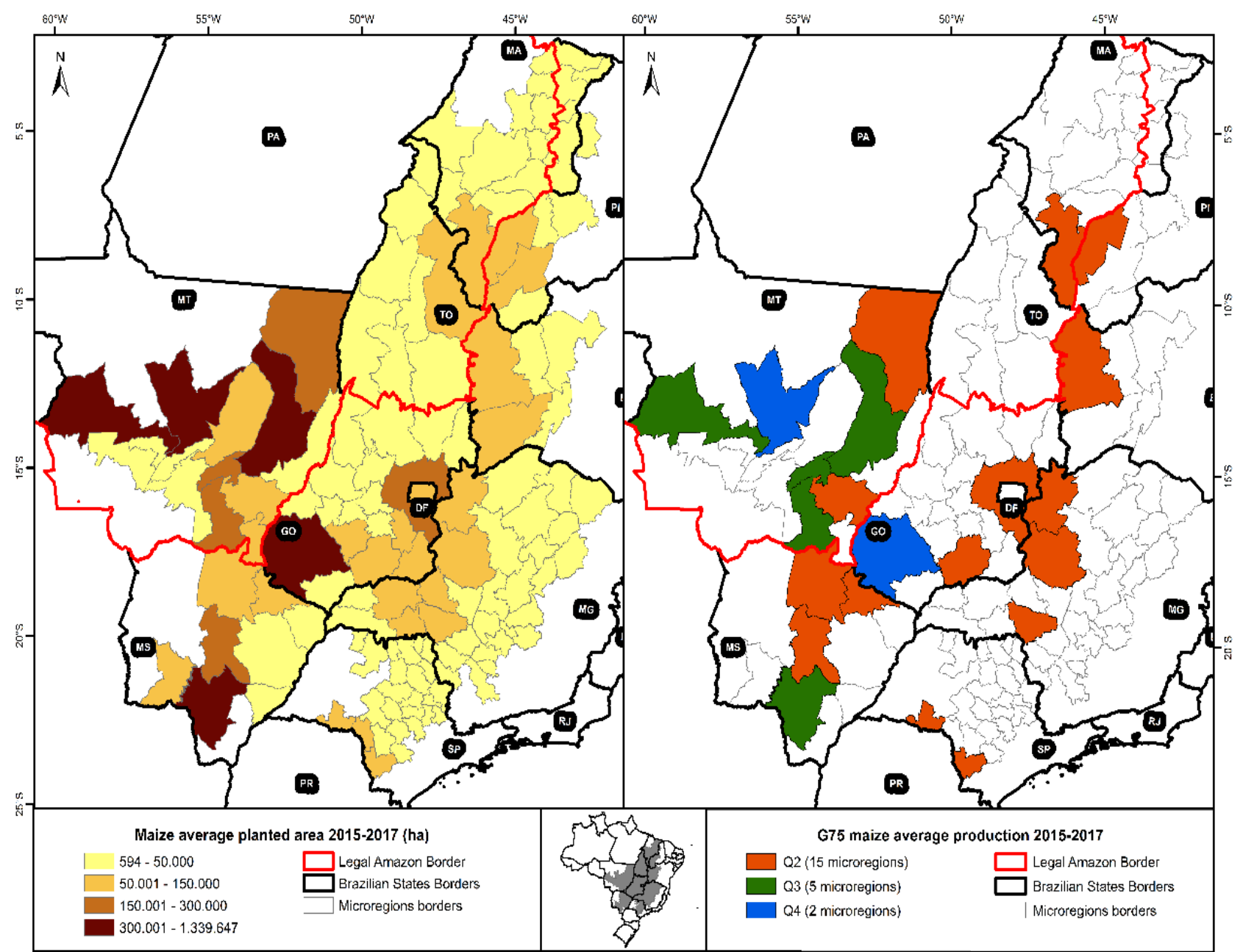

Fig. 10 Planted area and production groups (G75) for maize at the microregions within states in the Cerrado biome (average for the 2015/2016/2017 harvests). 

the Brazilian Rural Environmental Registry (Cadastro Ambiental Rural)

Table 6 Areas designated for environmental preservation in farms (2018) at G50's microregions (average for the 2015/2016/2017 harvests).

\begin{tabular}{lccc}
\hline \multirow{2}{*}{ Microregion } & \multicolumn{2}{c}{ G50 group (50\% of total production) } & \multirow{2}{*}{ ADP in farms (\%) } \\
\cline { 2 - 3 } & soy & corn & 52 \\
Norte Araguaia (MT) & $\mathrm{x}$ & & 46.3 \\
Barreiras (BA) & $\mathrm{x}$ & $\mathrm{x}$ & 42.7 \\
Alto Teles Pires (MT) & $\mathrm{x}$ & $\mathrm{x}$ & 42.6 \\
Parecis (MT) & $\mathrm{x}$ & $\mathrm{x}$ & 41.8 \\
Canarana (MT) & $\mathrm{x}$ & $\mathrm{x}$ & 39.7 \\
Around Brasília (GO) & $\mathrm{x}$ & $\mathrm{x}$ & 30.8 \\
Rondonópolis (MT) & & $\mathrm{x}$ & 29.2 \\
Southwest of Goiás (GO) & $\mathrm{x}$ & $\mathrm{x}$ & 22.6 \\
Primavera do Leste (MT) & $\mathrm{x}$ & & 17.5 \\
Dourados (MS) & &
\end{tabular}

In these regions, the Brazilian Forest Code demands that at least $20 \%$ of the farms' areas are preserved (Table 6). Mato Grosso's microregions show values ranging from $52 \%$ to $22.6 \%$. Within the Legal Amazon region, the Brazilian Forest Code demands that at least $35 \%$ of the farms' areas are preserved in the Cerrado biome, and $80 \%$ in the Amazon biome. Microregions in the north portion of the state of Mato Grosso, such as Norte Araguaia, where the Amazon biome predominates, show higher ADP values, such as $52 \%$. The remainder of Mato Grosso's microregions are mostly located in Cerrado.

Average planted area data on soybean and maize (first-harvest) account for $11 \%$ of the Cerrado region (Table 4). Among the microregions that produce 50\% of the country's total soybean and maize, Dourados (MS) shows the lowest ADP value, 17.5\%. However, throughout the remaining G50 microregions, areas designated for environmental preservation are larger than areas designated for soybean and maize production. The Norte Araguaia (MT), Alto Teles Pires (MT), Parecis (MT), Canarana (MT), Entorno de Brasília (GO) and Barreiras (BA) microregions designate at least three times more areas for environmental preservation than areas for annual crops. In other three microregions, Rondonópolis (MT), Primavera do Leste (MT) and Sudoeste de Goiás (GO), the ADP areas are at least twice the size of soybean and maize areas.
As aforementioned, Mato Grosso do Sul made only part of its SICAR data available, therefore the 17.5\% ADP value for Dourados (MS) is underestimated (Table 6).

\subsection{Sugarcane}

Brazil is the world's largest sugarcane producer. The crop's expansion throughout Cerrado started increasing in 2007, especially in Goiás and Mato Grosso do Sul, favored by ethanol production, a clean and renewable energy source fostered by federal public policies such as the Brazilian National Agroenergy Plan (Plano Nacional de Agroenergia, PNA) from 2006 to 2011. This expansion occurred primarily in agricultural areas used for annual crops, and secondarily in pasture areas, and tends to increase, because sugarcane showed the best average profitability among Brazilian agricultural activities in 2018, followed by soybean and maize [30-32].

The São José do Rio Preto, São Joaquim da Barra, Ribeirão Preto and Jaboticabal microregions in São Paulo, and Dourados microregion in Mato Grosso do Sul concentrate $25 \%$ of the Brazilian sugarcane production. The Meia Ponte microregion in Goiás, and the Uberaba and Frutal microregions in Minas Gerais, together with Araraquara, Assis and Jaú in São Paulo, concentrate $50 \%$ of the country's production and planted areas above 180 thousand hectares (Fig. 11). 


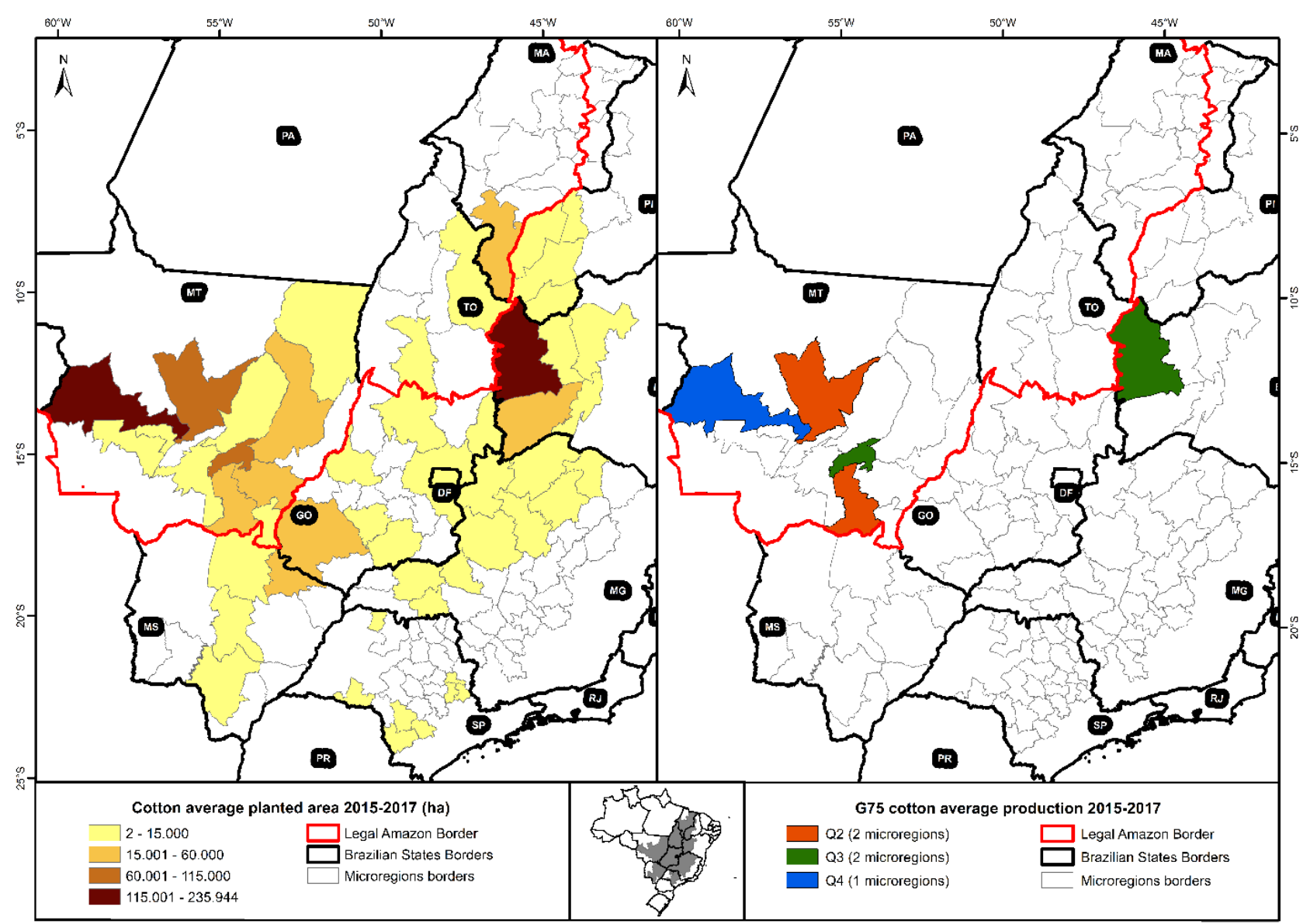

Fig. 11 Planted area and production groups (G75) for sugarcane at the microregions within states in the Cerrado biome (average for the 2015/2016/2017 harvests).

\subsection{Eucalyptus}

Eucalyptus crops account for $75 \%$ of the country's silvicultural production. The higher production value associated with eucalyptus crops is due to the fact that $53.7 \%$ of the Brazilian production is directed to the paper and pulp industry [33]. Eucalyptus production is divided into four main categories: logs for paper and pulp, logs for other uses, charcoal and fuelwood.

Each of these categories of eucalyptus produced in Cerrado have different production values: charcoal production has the strongest participation, with $43 \%$, followed by paper and pulp, with $31 \%$, then logs for other uses, with $13 \%$, and fuelwood, with $12 \%$ [34].

The Três Lagoas and Paranaíba microregions in Mato Grosso do Sul, Bauru in São Paulo, and Paracatu, Salinas and Capelinha in Minas Gerais stand out among the largest eucalyptus areas in Cerrado (Fig. 12 and (Table 7). In the Paranaíba (MS) microregion there was a strong expansion in eucalyptus crops in the last years, from 89 thousand hectares in 2013 to nearly 205 thousand in 2017. Because eucalyptus production begins six years after planting, Paranaíba is not featured among the group of main eucalyptus producers in this study, but might be in it in the coming years.

The microregions in Mato Grosso do Sul and São Paulo concentrate $50 \%$ of the total eucalyptus production for paper and pulp. Microregions in São Paulo and Minas Gerais stand out in the production of logs for other uses. Minas Gerais concentrates $50 \%$ of the production of eucalyptus charcoal. Eucalyptus production for fuelwood takes place in several states and is concentrated in Goiás, Minas Gerais, São Paulo and Mato Grosso do Sul (Fig. 15). 
102 Cerrado: Agricultural Production and Areas Designated for Environmental Preservation Registered in the Brazilian Rural Environmental Registry (Cadastro Ambiental Rural)

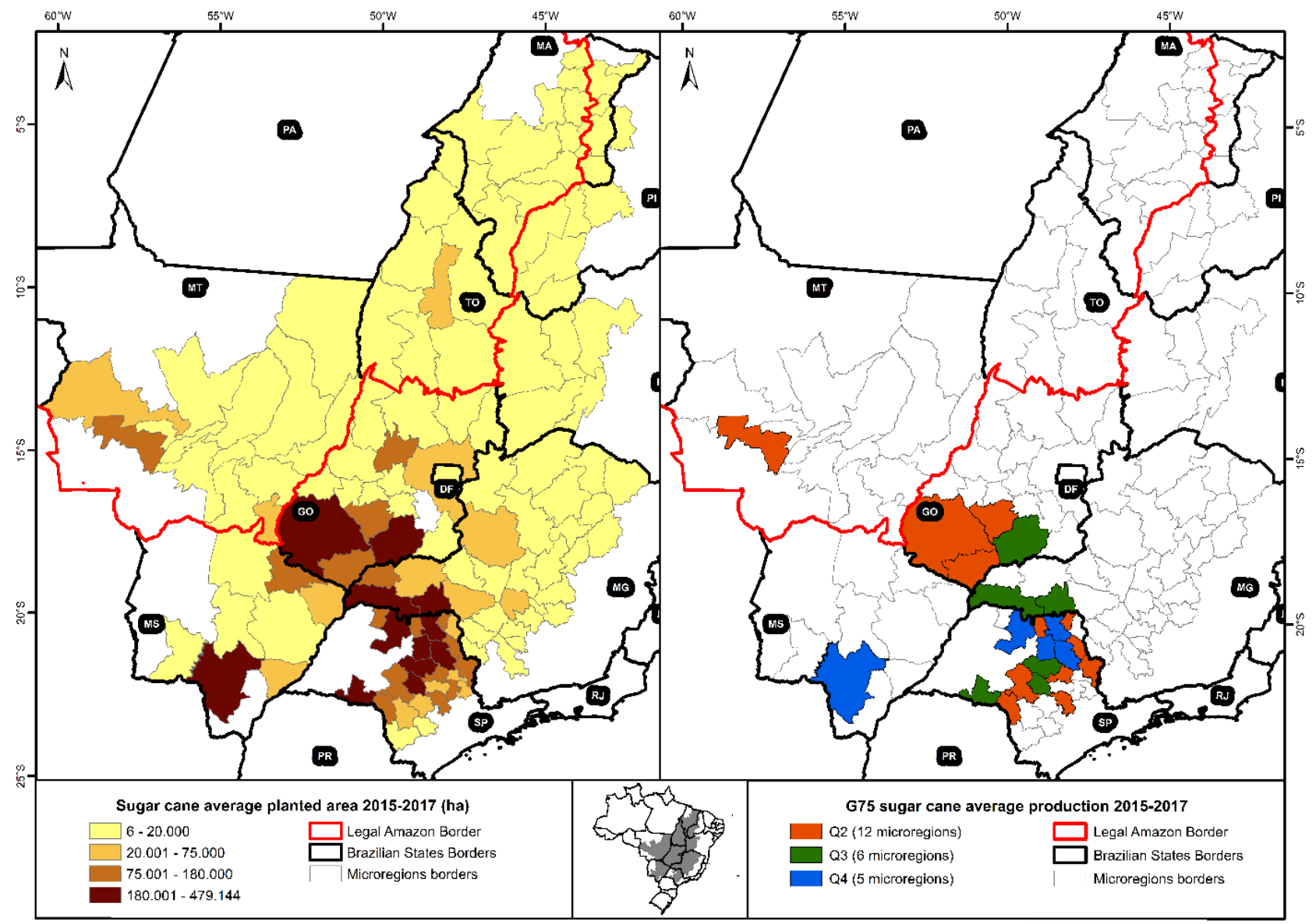

Fig. 12 Planted area for eucalyptus at the microregions within states in the Cerrado biome (average for the 2015/2016/2017 harvests).

Table 7 Areas designated for environmental preservation in farms (2018) at Brazil's G50 microregions for sugarcane and eucalyptus production (average for the $2015 / 2016 / 2017$ harvests).

\begin{tabular}{|c|c|c|c|c|c|c|}
\hline \multirow{3}{*}{ Microregion } & \multicolumn{5}{|c|}{ G50 group (50\% of total production) } & \multirow{3}{*}{ ADP in farms $(\%)$} \\
\hline & \multirow{2}{*}{ Sugar cane } & \multicolumn{4}{|c|}{ Eucalyptus } & \\
\hline & & paper and cel & $\log$ & coal & firewood & \\
\hline Jaboticabal (SP) & $\mathrm{x}$ & & & & & 10.9 \\
\hline São Joaquim da Barra (SP) & $\mathrm{x}$ & & & & & 11.9 \\
\hline São José do Rio Preto (SP) & $\mathrm{x}$ & & & & & 14.3 \\
\hline Ribeirão Preto (SP) & $\mathrm{x}$ & & & & & 17.2 \\
\hline Dourados (MS) & $\mathrm{x}$ & & & & & 17.5 \\
\hline Bauru (SP) & & $\mathrm{x}$ & $\mathrm{x}$ & & $\mathrm{x}$ & 17.6 \\
\hline Frutal (MG) & $\mathrm{x}$ & & & & & 18.3 \\
\hline Avaré (SP) & & & $\mathrm{x}$ & & & 18.4 \\
\hline Três Lagoas (MS) & & $\mathrm{x}$ & & & & 20.4 \\
\hline Piracicaba (SP) & & & & & $\mathrm{x}$ & 20.7 \\
\hline Meia Ponte (GO) & $\mathrm{x}$ & & & & & 22.7 \\
\hline Itapetininga (SP) & & $\mathrm{x}$ & $\mathrm{x}$ & & $\mathrm{x}$ & 22.8 \\
\hline Botucatu (SP) & & & $\mathrm{x}$ & & & 22.9 \\
\hline Uberlândia (MG) & & & $\mathrm{x}$ & & $\mathrm{x}$ & 23 \\
\hline Uberaba (MG) & $\mathrm{x}$ & & & & & 24.1 \\
\hline Itapeva (SP) & & $\mathrm{x}$ & & & $\mathrm{x}$ & 24.3 \\
\hline
\end{tabular}



the Brazilian Rural Environmental Registry (Cadastro Ambiental Rural)

Table 7 to be continued

\begin{tabular}{llll}
\hline Formiga (MG) & & $\mathrm{x}$ & 25.8 \\
Passos (MG) & & $\mathrm{x}$ & 25.9 \\
Patrocínio (MG) & & $\mathrm{x}$ & 30.6 \\
Salinas (MG) & & $\mathrm{x}$ & 37.2 \\
Capelinha (MG) & $\mathrm{x}$ & $\mathrm{x}$ & 38.5 \\
Paracatu (MG) & & $\mathrm{x}$ & 39.8 \\
Três Marias (MG) & $\mathrm{x}$ & $\mathrm{x}$ & 42.5 \\
Pirapora (MG) & & 47.2 \\
\hline
\end{tabular}
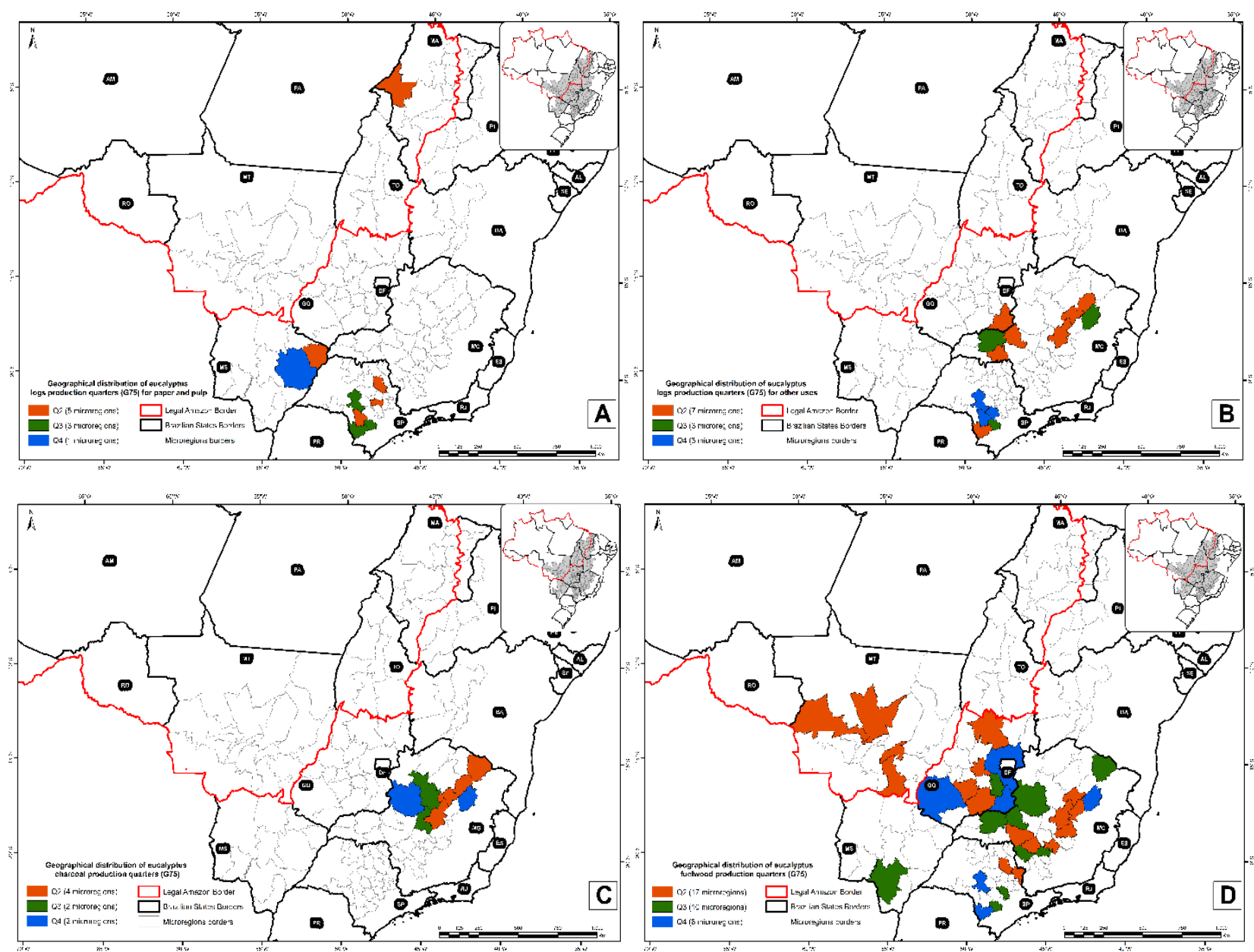

Fig. 13 Eucalyptus production at the microregions within states in the Cerrado biome (average for the 2015/2016/2017 harvests). Production of (A) logs for paper and cellulose (in cubic meters), (B) logs for other uses (in cubic meters), (C) charcoal (in tons), and (D) fuelwood (in cubic meters).

ADP values for sugarcane vary between 10.9 and $24.1 \%$ among microregions in the states of São Paulo, Minas Gerais, Mato Grosso do Sul and Goiás (Table 7). The territories occupied with eucalyptus crops change according to the crop's objectives. Crops for pulp and paper are concentrated in microregions in the states of Mato Grosso do Sul and São Paulo, whereas crops for log production for other uses and for fuelwood are concentrated in the states of São Paulo and Minas Gerais. Charcoal production is concentrated in Minas Gerais. The microregions in Cerrado which concentrate eucalyptus productions show ADPs ranging between 17.6 in Bauru (SP) and 47.2 in Pirapora (MG) (Table 7). 

the Brazilian Rural Environmental Registry (Cadastro Ambiental Rural)

\section{Conclusions}

The Brazilian Forest Code demands that all farms equal to or larger than four fiscal modules designate at least $20 \%$ of their total areas to the permanent preservation of natural plant cover in Cerrado areas, and at least $35 \%$ in Cerrado areas within Legal Amazon's boundaries.

In the Cerrado areas analyzed in this study, $40.3 \%$ of the territory is designated for environmental preservation within farms, which designate $14.5 \%$ of their areas for main annual and perennial crops.

Hirakuri [35] state that after the Soybean Moratorium in 2006, the expansion of soybean crops is no longer an important cause for deforestation in Cerrado. The crop's technological development has been the major factor to its advancement. New cultivars and management technologies for soil and crop are launched steadily. The data published in this study show that, in a large territory such as Matopiba, which depicts well the country's agricultural boundary expansion, $55 \%$ of the farms are occupied by preservation areas, which amount to over $30 \%$ of the whole region (Table 5). Microregions in Maranhão and Piauí are part of the G75 production group for soybean and maize, and the amount of areas designated for environmental preservation surpass 40\% in Piauí and 60\% in Maranhão (Fig. 7).

Crops such as sugarcane and eucalyptus, which are traditionally grown in São Paulo and Minas Gerais, also showed strong expansion into the Central-West region, especially Goiás and Mato Grosso, over the last decades.

An example of agricultural production expansion in Cerrado is shown in [36]. They evaluated the expansion of sugarcane crops in the states of Goiás and DF between 2003 and 2013. According to their analysis, sugarcane areas increased six times in this period, from 142 thousand hectares to 847 thousand hectares, and $62 \%$ of this expansion occurred onto pasture areas, and $38 \%$ onto soybean areas. Only $6 \%$ of this expansion relied on the use of new Cerrado areas.
Land-use intensification by producing two or three successive harvests in a year has increased the country's agricultural production for annual crops and pastures without the need for using new areas [37, 38]. Studies show that agricultural intensification may result in the use of less areas, especially when associated with economic and environmental planning on a landscape and watershed level. Thus, there is room for the expansion of the agricultural industry while abiding by the Brazilian Forest Code and maintaining the country's biodiversity and ecosystem services, as shown in this territory analysis [36-39].

Mato Grosso is the country's leader in agricultural production for soybean, maize and cotton, and its farmers designate $44 \%$ of their farms for environmental preservation. This shows that farmers are accountable for the country's environmental preservation and contribute to it by maintaining and conserving the native vegetation areas within their farms [23].

Areas designated for environmental preservation promote several ecosystem services, such as soil and water preservation, conservation and rehabilitation of ecological processes such as the pollination of fruit and annual crops, natural biodiversity conservation and shelter against natural enemies that control plagues and diseases [40]. Besides, the microclimate created by forest formations aids the nearby crops [41]. The data shown in this study support the Brazilian Forest Code as an instrument that combines agricultural production and environmental preservation, and as such it may aid farmers and the country's environmental preservation efforts to increase and develop themselves together.

Discussing whether these values are considered adequate, high or low was not our goal in this study, because a qualitative assessment would depend on jointly analyzing the multiple environmental factors involved. Embrapa Territorial has been carrying out studies on the biodiversity of the phytophysiognomies of APP and RL areas within Cerrado regions. These studies may further contribute to assessments on the 


\section{Cerrado: Agricultural Production and Areas Designated for Environmental Preservation Registered in the Brazilian Rural Environmental Registry (Cadastro Ambiental Rural)}

conditions of these environmental preservation areas in the future.

\section{References}

[1] CONTINI, E. Exportações na dinâmica do agronegócio brasileiro: oportunidades econômicas e responsabilidade mundial. In: BUAINAIN, A. M..

[2] FONTES, E. M. G.; SOUZA RAMALHO, F. de; UNDERWOOD, E.; BARROSO, P. A. V.; SIMON, M. F.; SUJII, E. R.; PIRES, C. S. S.; BELTRÃO, N.; LUCENA, W. A.; FREIRE, E. C. The cotton agricultural context in Brazil. In: HILBECK, A.; ANDOW, D. A.; FONTES, E. M. G.; KAPUSCINSKI, A. R.; SCHEI, P. J. (Ed.). Environmental risk assessment of genetically modified organisms: methodologies for assessing $\mathrm{Bt}$ cotton in Brazil. Wallingford, UK: CABI Publishing, 2006. v. 2. p. 21-66. (Environmental risk assessment of genetically modified organisms series, v. 2).

[3] BRASIL. Ministério da Agricultura, Pecuária e Abastecimento. Agropecuária brasileira em números. 2019. Available

in: <http://www.agricultura.gov.br/assuntos/politica-agricola /todas-publicacoes-de-politica-agricola/outras-publicacoe s/201902-agropecuaria-brasileira-em-numeros>.

Accessed on: Feb. 13, 2019.

[4] FALEIRO, F. G.; FARIAS NETO, A. L. de (Ed.). Savanas: demandas para pesquisa. Planaltina, DF: Embrapa Cerrados, 2009. $170 \mathrm{p}$.

[5] FEARNSIDE, P.M. Environmental Conservation, v. 28, p. 3-38, 2001.

[6] PARRON, L. M.; SÁ, M. A. C.; MARCHI, G.; MARCHÃO, R. L.; GUIMARÃES JUNIOR, R.; OLIVEIRA-FILHO, E. C. Impactos dos sistemas de produção e estratégias de mitigação: demandas para a pesquisa. In: FALEIRO, F. G.; FARIAS NETO, A. L. (Ed.). Savanas: demandas para pesquisa. Planaltina, DF: Embrapa Cerrados, 2009. p. 69-78.

[7] SPERA, S. A.; VANWEY, L.; MUSTARD, J. The drivers of sugarcane expansion in Goiás, Brazil. The drivers of sugarcane expansion in Goiás, Brazil. Land Use Policy, v. 66, p. 111-119, 2017.

[8] LOPES, A. S.; DAHER, E. Agronegócio e recursos naturais no cerrado: desafios para a coexistência harmônica. In: FALEIRO, F. G.; FARIAS NETO, A. L. (Ed.). Savanas: desafios e estratégias para o equilíbrio entre sociedade, agronegócio e recursos naturais. Planaltina, DF: Embrapa Cerrados, 2008. p. 173-209. Chapter 5.

[9] CASTRO, A. S.; ROSSI JUNIOR, J. L. Modelos de previsão para a exportação das principais commodities brasileiras. Rio de Janeiro: Instituto de Pesquisa
Econômica Aplicada (Ipea), 2000. (Texto para discussão, 716). Available in: $<$ http://repositorio.ipea.gov.br/bitstream/11058/2311/1/T D_716.pdf $>$. Accessed on: July 1, 2019.

[10] FREIRE, E. C. História do algodão no cerrado. In: Algodão: no cerrado do Brasil. 2. ed. Brasília, DF: Abrapa, 2011. p. 23-59. Chapter 1.

[11] VIEIRA FILHO, J. E. R. Expansão da fronteira agrícola no Brasil: desafios e perspectivas. Brasília, DF: Instituto de Pesquisa Econômica Aplicada, 2016. (Texto para discussão, 2223).

[12] IBGE. Mapa de Biomas e de Vegetação. 2004. Available in:

<https://ww2.ibge.gov.br/home/presidencia/noticias/2105 2004biomashtml.shtm>. Accessed on: Jan. 21, 2019.

[13] OLIVEIRA-FILHO, A. T.; RATTER, J. A. Vegetation Physiognomies and Woody Flora of the Cerrado Biome. In: OLIVEIRA, P. S.; MARQUIS, R. J. (Ed.). The cerrados of Brazil: ecology and natural history of a neotropical savanna. New York: Columbia University Press, 2002. p. 91-120.

[14] RIBEIRO, J. F.; WALTER, B. M. T. Fitofisionomias do bioma cerrado. In: SANO, S. M.; ALMEIDA, S. P. (Ed.). Cerrado: ambiente e flora. Planaltina: Embrapa-CPAC, 1998. p. 87-166. Chapter 3.

[15] SANO, E. E.; ROSA, R.; BRITO, J. L. S.; FERREIRA, L. G. Land cover mapping of the tropical savanna region in Brazil. Environ Monit Assess, v. 166, p. 113-124, 2010.

[16] GARAGORRY, F. L.; CHAIB FILHO, H. Elementos de agrodinâmica. Brasília, DF: Embrapa SGE, 2008. Available

in: $<$ http://www22.sede.embrapa.br/web/sge01/estatisticaagri cola/dinamica/relatorioagrodinamica.pdf $>$. Accessed on: Jan. 15, 2018.

[17] SFB. Cadastro Ambiental Rural. Available in: $<$ http://www.car.gov.br/publico/imoveis/index>.

Accessed on: Oct. 22, 2019.

[18] MIRANDA, E. E. de; CARVALHO, C. A. de; OSHIRO, O. T.; MARTINHO, P. R. R.; MAGALHÃES, L. A.; CASTRO, G. S. A. Number, maps and facts: Agriculture leads environmental preservation. Proceedings of the First International Conference on Agro Big Data and Decision Support Systems in Agriculture September 27-29 2017, Montevideo, Uruguay. Available in: $<$ https://www.embrapa.br/territorial/busca-de-publicacoes /-/publicacao/1078639/number-maps-and-facts-agricultur e-leads-environmental-preservation>. Accessed on: Oct. 22, 2019.

[19] EMBRAPA. Agricultura e preservação ambiental: uma análise do Cadastro Ambiental Rural - Material e Métodos. Available in: $<$ https://www.embrapa.br/en/car/material-metodos>. 
Accessed on: Oct. 22, 2019.

[20] ESRI. ArcGIS 10.7. Available in: $<$ http://www.esri.com/software/arcgis/arcgis-for-desktop >. Accessed on: Oct. 22, 2019a.

[21] GOOGLE. Google Earth Pro. Available in: $<$ https://www.google.com/work/mapsearth/products/earth pro.html>. Accessed on: Oct. 22, 2019.

[22] ESRI. ArcGIS File Geodatabases. Available in: $<$ https://desktop.arcgis.com/en/arcmap/10.3/manage-data/ administer-file-gdbs/file-geodatabases.htm>. Accessed on: Oct. 22, 2019b.

[23] R CORE TEAM. A language and environment for statistical computing. Viena, AU: R Foundation forStatistical Computing, 2016. Available in: $<$ https://www.R-project.org/>. Accessed on: Sept. 5, 2018.

[24] MIRANDA, E. E. de. Tons de verde: a sustentabilidade da agricultura no Brasil. São Paulo: MetaLivros, 2018. 218 p.

[25] SICAR. Sistema Nacional do Cadastro Ambiental Rural. 2018. Available in: $<$ www.car.gov.br/publico/imoveis/index>. Accessed on: Jan. 8, 2018.

[26] IBGE. Sistema IBGE de Recuperação Automática SIDRA. Censo Agropecuário. Available in: $<$ http://www.sidra.ibge.gov.br>. Accessed on: Sept. 17, 2019.

[27] INCRA. Instituto Nacional de Colonização e Reforma Agrária. Tabela com módulo fiscal dos municípios. Available in: $\quad<$ http://www.incra.gov.br/tabela-modulo-fiscal $>$. Accessed on: Jan. 10, 2018.

[28] BRITO, M. Modelo Sustentável para a produção agropecuária. Agroanalysis, v. 39, n. 3, p. 49-50, March, $2019 . \quad$ Available in: $<$ http://www.agroanalysis.com.br/storage/2019/3/index.ht ml\#page $=1>$. Accessed on: July 1, 2019.

[29] GAZZONI, D. L. A sustentabilidade da soja no contexto do agronegócio brasileiro e mundial. Londrina, PR: Embrapa Soja, 2013. (Documentos, 344).

[30] MARTINELLI, L. A.; BATISTELLA, M.; SILVA, R. F. B.; MORAN, E. Soy expansion and socioeconomic development in municipalities of Brazil. Land, n. 3, v. 6, 2017. Available in: $<$ https://www.mdpi.com/2073-445X/6/3/62>. Accessed on: Oct. 15, 2018.

[31] BARBALHO, M. G. S.; SILVA, A. A.; CASTRO, S. S.A expansão da área de cultivo da cana-de-açúcar na região sul do estado de Goiás de 2001 a 2011. Revista Brasileira de Ciências Ambientais, n. 29, p. 98-110, Sept. 2013.

[32] CASTRO, S. S.; ABDALA, K.; SILVA, A. A.; BORGES, V. M. S. A expansão da cana-de-açúcar no cerrado e no estado de Goiás: elementos para uma análise espacial do processo. Boletim Goiano de Geografia, n. 1, v. 30, p.
171-190, Jan./June, 2010.

[33] LIMA FILHO, R. R.; PILA, J. Resultado de 2018 e expectativas para 2019. Agroanalysis, n. 3, v.39, p. 24-26, March, 2019. Available in: $<$ http://www.agroanalysis.com.br/storage/2019/3/index.ht ml\#page=1>. Acesso: July 1, 2019.

[34] SANTAROSA, E.; PENTEADO JUNIOR, J. F.; GOULART, I. C. G. R. (Ed.). Transferência de tecnologia florestal: cultivo de eucalipto em propriedades rurais: diversificação da produção e renda. Brasília, DF: Embrapa, 2014.

[35] IBGE. Sistema IBGE de Recuperação Automática SIDRA. Censo Agropecuário. Available in: $<$ http://www.sidra.ibge.gov.br>. Accessed on: Out. 22, 2018.

[36] HIRAKURI, M. H.; CASTRO, C. de; FRANCHINI, J. C.; DEBIASI, H.; PROCOPIO, S. de O.; BALBINOT JUNIOR, A. A. Indicadores de sustentabilidade da cadeia produtiva da soja no Brasil.Londrina: Embrapa Soja, 2014.70 p. (Documentos, 351).

[37] SPERA, S. Agricultural intensification can preserve the Brazilian Cerrado: applying lessons from Mato Grosso and Goiás to Brazil's last agricultural frontier. Tropical Conservation Science, v. 10, p. 1-7, 2017.

[38] MARANHÃO, R. L. A.; VIEIRA FILHO, J. E. R. A dinâmica do crescimento das exportações do agronegócio brasileiro. Brasília, DF: Instituto de Pesquisa Econômica Aplicada (Ipea), 2016. (Texto para discussão, 2249). Available in: <http://www.ipea.gov.br/portal/images/stories/PDFs/TDs/ td_2249v.pdf $>$. Accessed on: July 1, 2019.

[39] GOLDSMITH, P.; COHN, A. Commercial agriculture in tropical environments. special issue: commercial agriculture in tropical environments. Tropical Conservation Science, v. 10, p. 1-4, 2017.

[40] KENNEDY, C.; HAWTHORNE, P. L.; MITEVA, da; BAUMGARTEN, L.; SOCHI, K.; MATSUMOTO, M.; EVANS, J. S.; POLASKY, S.; HAMEL, P.; VIEIRA, E. M.; DEVELEY, P. F.; SEKERCIOGLU, C. H.; DAVIDSON, A. D.; UHLHORN, E. M.; KIESECKER, J. Optimizing land use decision-making to sustain Brazilian agricultural profits, biodiversity and ecosystem services. Biological Conservation, v. 204, p. 221-230, 2016.

[41] METZGER, J. P.; BUSTAMANTE, M. M. C.; FERREIRA, J.; FERNANDES, G. W.; LIBRÁN-EMBID, F.; PILLAR, V. D.; PRIST, P. R.; RODRIGUES, R. R.; VIEIRA, I. C. G.; OVERBECK, G. E. Why Brazil needs its Legal Reserves. Perspectives in Ecology and Conservation, n. 17, p. 91-103, 2019.

[42] MANGABEIRA, J. A. de C.; TÔSTO, S. G.; ROMEIRO, A. R.; GREGO, C. R. Análise espacial aplicada à valoração de serviços ecossistêmicos da agricultura: 
Cerrado: Agricultural Production and Areas Designated for Environmental Preservation Registered in the Brazilian Rural Environmental Registry (Cadastro Ambiental Rural)

exemplo do café em Machadinho d'Oeste, RO. In: TÔSTO, S. G.; BELARMINO, L. C.; ROMEIRO, A. R.; ecossistêmicos: metodologias e estudos de caso. Brasília, RODRIGUES, C. A. G. (Ed.). Valoração de serviços DF: Embrapa Monitoramento por Satélite, 2015. P.53-70. Chapter 3. 